Ann. Biol. anim. Bioch. Biophys., 1978, 18 (4), 985-990.

\title{
Induced spawning of Sparus aurata (L.) by means of hormonal treatments
}

par H. GORDIN, Y. ZOHAR

Israel Oceanographic and Limnological Research Ltd. Mariculture Laboratory, P.O.B. 1212, Elat, Israel.

Summary. This paper reports experiments done in induced spawning of Sparus aurato during two breeding seasons : 1975/76 and 1976/77. Reared in captivity in the Elat Mariculture Laboratory, this species did not spawn spontaneously. In the 1975/76 season, HCG was injected IM using doses up to $2700 \mathrm{IU} / \mathrm{kg}$ of fish. Each treatment was run in a separate tank which held a few females and males. Many of the fish shed either unripe or aged eggs. The experimental method did not allow detailed analysis of treatments.

During the 1976/77 season, each female used in the experiments was held in a separate tank. HCG calibration experiments, based on the vitellogenetic stage of the oocytes, were carried out. Doses found to be sufficient to cause ovulation and spawning of viable eggs ranged from 100 to $1200 \mathrm{lU} / \mathrm{kg}$ fish. S. aurata's natural spawning season is believed to last six weeks. Due to the HCG treatments, the spawning season was extended to five and a half months.

\section{Introduction.}

One of the basic requirements for fish culture programs is that the entire life cycle of the species should be completed in captivity. Many of the fish which serve in such programs do not breed spontaneously under such conditions. Hence, an induced spawning technique must be applied.

The gilthead seabream Sparus aurata is thought to have a great potential for mariculture. In its natural environment in the eastern Mediterranean, S. aurata breeds once a year during a six-week period from the middle of December through the end of January. In captivity this species does not spawn spontaneously (Arias, 1976 ; Villani, 1976). Our detailed histological studies (Zohar, 1976 ; Zohar ef al., in preparation) showed that in $S$. aurata ovarian development is not completed; oocytes develop to the last stages of vitellogenesis and then undergo atresia. On the other hand, testicular development is completed. 
The most potent ovulation and spawning-inducers in hypophysectomized fish and in fish in which spawning does not occur spontaneously were found to be fish pituitary extracts, fish gonadotropins and mammalian gonadotropins (mainly LH, HCG and PMS) (see reviews by Shehadeh, 1970 ; de Vlaming, 1974).

Ovulation and spawning in S. aurata have been induced by means of HCG treatments (Barnabé and René, 1973 ; Lumare and Villani, 1973 ; Alessio and Bronzi, 1974 ; Alessio et al., 1975, 1976 ; Arias, 1976 ; Barnabé, 1976 ; San Feliu et al., 1976 ; Villani, 1976). Effective doses ranged from 3500 to $15000 \mathrm{IU} /$ fish. A previous study done in our laboratory showed that HCG doses of 800 to $2000 \mathrm{IU} / \mathrm{kg}$ fish were effective in inducing spawning, whereas carp pituitary extract was ineffective.

This paper reports on experiments carried out during the years 1976 and 1977 to study (1) the efficiency of HCG as an ovulation and spawning-inducing agent in captivity-reared Sparus aurata in Elat and (2) the relations between oocyte vitellogenetic stage and the HCG dose required to induce completion of oocyte develop. ment, ovulation and spawning.

\section{Materials and methods.}

The fish used in the present study were collected as fry from their natural habitat in the Mediterranean and were stocked in outdoor experimental tanks. Two and three-year old fish were treated. Experiments were run during two breeding seasons. In 1976, experiments started on January 15th and lasted two months. During this period, HCG was tested as an ovulation and spawning-inducing agent. During 1976/1977, experiments started on November 23rd and the spawning period ended in the middle of May.

All treated fish were anesthetized in $1: 20000$ dilution of MS 222 (Sandoz). An ovarian biopsy was done prior to each treatment by sucking a small tissue sample into an hematocrite capillary tube inserted into the ovary through the ovipore. The fresh biopsy was used to determine oocyte developmental stage. Only females with vitellogenetic oocytes were used in the study. Following the biopsy, females were injected with the hormone either intraperitonially or intramuscularly. Control fish were injected with 0.9 p. $100 \mathrm{NaCl}$ solution. The total dose of the hormone was administered by 1 or 2 injections. A second injection was given 48 hrs after the first one, following a second ovarian biopsy. Every treatment was followed by a chloramphenicol injection at a dose of $50 \mathrm{mg} / \mathrm{kg}$ fish. During the 1976 experiments, a few females exposed to treatment were stocked in the same outdoor tank together with a few mature untreated males. During the 1976/77 experiments, each treated female was stocked in a separate tank together with two males. An open circulation system supplied the experimental tanks with Gulf of Elat seawater. Fish were maintained on artificial feed.

Spawned eggs were fertilized naturally by untreated males present in the experimental tanks. The eggs were collected and counted daily and fertilization percentage was determined. 


\section{Results.}

The results of the work carried out during the 1976 and 1977 spawning periods of S. aurata are presented in table 1 and table 2, respectively. During the 1976 spawning experiments, more than one female was held in each tank, hence the results are related to treatments and not to individual fishes. In the following year, each treated female was held in its own tank; therefore results are related to individual fishes. During both years, most treated females completed oocyte maturation and ovulation but not all of them spawned. Unspawed eggs underwent rapid reabsorption.

In general terms, the experiments of winter 1976 demonstrated that HCG doses ranging from $700-2700 \mathrm{IU} / \mathrm{kg}$ fish were effective in inducing completion of oocyte development, ovulation and spawning (table 1). In winter 1976/1977, it was shown

TABLE 1

The effect of human chorionic gonadotropin (HCG) $\left.{ }^{1}\right)$ on ovulation and spawning of females of Sparus aurata during winter 1976

\begin{tabular}{|c|c|c|c|c|c|c|c|}
\hline $\begin{array}{l}\text { No. of } \\
\text { fish }\end{array}$ & $\begin{array}{l}\text { No. of } \\
\text { injections }\end{array}$ & $\begin{array}{l}\text { Dose per injec- } \\
\text { tion } / \mathrm{kg} \text { fish }\left({ }^{2}\right)\end{array}$ & $\begin{array}{l}\text { Total dose } \\
\text { Ul/kg fish }\end{array}$ & $\begin{array}{l}\text { Ovula } \\
+\end{array}$ & on & Spawning & Eggs qualify \\
\hline $\begin{array}{r}3 \\
2 \\
2 \\
15 \\
4 \\
3 \\
2 \\
4\end{array}$ & $\begin{array}{l}1 \\
2 \\
2 \\
2 \\
2 \\
3 \\
2 \\
3\end{array}$ & $\begin{array}{l}700 \\
500-700\left(^{4}\right) \\
500-1200 \\
700-1000 \\
700-1200 \\
500-1000-500 \\
1200-1000 \\
700-1000-1000\end{array}$ & $\begin{array}{l}700 \\
1200 \\
1700 \\
1700 \\
1900 \\
2000 \\
2200 \\
2700\end{array}$ & $\begin{array}{l}3\left({ }^{3}\right) \\
2 \\
1 \\
11 \\
2 \\
3 \\
1 \\
4\end{array}$ & $\begin{array}{l}0 \\
0 \\
1 \\
4 \\
2 \\
0 \\
1 \\
0\end{array}$ & $\begin{array}{l}+ \\
+ \\
+ \\
+ \\
+ \\
+ \\
+\end{array}$ & $\begin{array}{c}\text { poor } \\
\text { poor } \\
\text { partly good } \\
\text { partly good } \\
\text { poor } \\
\text { poor }\end{array}$ \\
\hline
\end{tabular}

(1) Sigma Chemical Company CG-2.

(2) All females were injected intramuscularly.

(3) Figures indicate number of fish.

(4) First, second and third figures correspond to first, second and third injections, respectively.

that HCG doses as low as $100-200 \mathrm{lU} / \mathrm{kg}$ fish were very effective in inducing the same process, if administered to females in which oocytes were in a more advanced vitellogenetic stage. It was also found that the quantity of HCG needed to induce completion of oocyte development, ovulation and spawning was in inverse relation to the developmental stage of the vitellogenetic oocytes (table 2). As a result of the HCG treatment during winter 1976/1977, the spawning season of Sparus aurata lasted from November 30th to May 21st. A large number of viable eggs were spawned by each female (up to 1 million) and the percentage of fertilization was found to be high (table 2). Survival rates of larvae hatched from eggs which had been spawned by hormone-treated females did not differ from those of larvae hatched from eggs which had been spawned naturally in 2 unusual cases (unpublished data). 
TABLE 2

The effect of human chorionic gonadotropin (HCG) on ovulation and spawning of females of Sparus aurata during winfer 1976/77

\begin{tabular}{|c|c|c|c|c|c|c|c|c|c|c|}
\hline $\begin{array}{l}\text { Initial } \\
\text { egg } \varnothing\end{array}$ & $\begin{array}{l}\text { No. of } \\
\text { fish }\end{array}$ & $\begin{array}{l}\text { No. of } \\
\text { injections }\end{array}$ & $\begin{array}{l}\text { Dose per } \\
\text { injection } / \mathrm{kg} \text { fish }\end{array}$ & $\begin{array}{l}\text { Total dose } \\
\text { Ul } / \mathrm{kg} \text { fish }\end{array}$ & Orul & Iation & Span & ning & $\begin{array}{l}\text { No. of } \\
\text { eggs }{ }^{(1)}\end{array}$ & $\begin{array}{c}\text { p. } 100 \\
\text { fertilization }\end{array}$ \\
\hline $200-300$ & $\begin{array}{l}2 \\
1 \\
3 \\
2 \\
2\end{array}$ & $\begin{array}{l}3 \\
3 \\
3 \\
3 \\
3\end{array}$ & $\begin{array}{l}100\left(^{(2)}\right. \\
200 \\
400 \\
600 \\
800\end{array}$ & $\begin{array}{r}300 \\
600 \\
1200 \\
1800 \\
2400\end{array}$ & $\begin{array}{l}0 \\
1 \\
3 \\
2 \\
2\end{array}$ & $\begin{array}{l}2\left(^{3}\right) \\
0 \\
0 \\
0 \\
0\end{array}$ & $\begin{array}{l}0 \\
0 \\
2 \\
1 \\
0\end{array}$ & $\begin{array}{l}2 \\
1 \\
1 \\
1 \\
2\end{array}$ & $\begin{array}{c}- \\
\text { not counied } \\
\text { not counted } \\
-\end{array}$ & $\begin{array}{l}- \\
\text { low } \\
\text { low } \\
-\end{array}$ \\
\hline $301-400$ & $\begin{array}{l}1 \\
1 \\
2\end{array}$ & $\begin{array}{l}2 \\
2 \\
2\end{array}$ & $\begin{array}{l}150(\text { IP) } \\
400-200\left({ }^{4}\right) \\
400\end{array}$ & $\begin{array}{l}300 \\
600 \\
800\end{array}$ & $\begin{array}{l}1 \\
1 \\
2\end{array}$ & $\begin{array}{l}0 \\
0 \\
0\end{array}$ & $\begin{array}{l}1 \\
0 \\
0\end{array}$ & $\begin{array}{l}0 \\
1 \\
2\end{array}$ & $\begin{array}{l}641210 \\
-\end{array}$ & $\begin{array}{c}95-100 \\
-\end{array}$ \\
\hline $401-450$ & $\begin{array}{l}1 \\
1 \\
2 \\
2\end{array}$ & $\begin{array}{l}2 \\
1 \\
2 \\
2\end{array}$ & $\begin{array}{l}200 \\
400 \\
400-200 \\
400\end{array}$ & $\begin{array}{l}400 \\
400 \\
600 \\
800\end{array}$ & $\begin{array}{l}1 \\
1 \\
2 \\
2\end{array}$ & $\begin{array}{l}0 \\
0 \\
0 \\
0\end{array}$ & $\begin{array}{l}1 \\
1 \\
1 \\
2\end{array}$ & $\left.\begin{array}{l}0 \\
0 \\
1 \\
0\end{array}\right\}$ & $\begin{array}{l}33000 \\
37400 \\
90000\end{array}$ & $\begin{array}{r}50-90 \\
92 \\
50\end{array}$ \\
\hline 451.500 & $\begin{array}{l}1 \\
3 \\
1\end{array}$ & $\begin{array}{l}1 \\
2 \\
2\end{array}$ & $\begin{array}{l}200 \\
200 \\
400-200\end{array}$ & $\begin{array}{l}200 \\
400 \\
600\end{array}$ & $\begin{array}{l}1 \\
2 \\
0\end{array}$ & $\begin{array}{l}0 \\
1 \\
1\end{array}$ & $\begin{array}{l}1 \\
2 \\
0\end{array}$ & $\begin{array}{l}0 \\
1 \\
1\end{array}$ & $\begin{array}{r}35000 \\
150000 \\
-\end{array}$ & $\begin{array}{c}95-1 \mathrm{po} \\
85 \\
-\end{array}$ \\
\hline $501-525$ & $\begin{array}{l}1 \\
3 \\
1 \\
1 \\
2\end{array}$ & $\begin{array}{l}1 \\
1 \\
2 \\
2 \\
2\end{array}$ & $\begin{array}{l}150 \\
200 \\
150 \text { (IP) } \\
200-100 \\
200-150\end{array}$ & $\begin{array}{l}150 \\
200 \\
300 \\
300 \\
450\end{array}$ & $\begin{array}{l}1 \\
3 \\
1 \\
1 \\
2\end{array}$ & $\begin{array}{l}0 \\
0 \\
0 \\
0 \\
0\end{array}$ & $\begin{array}{l}0 \\
2 \\
1 \\
1 \\
2\end{array}$ & $\begin{array}{l}1 \\
1 \\
0 \\
0 \\
0\end{array}$ & $\begin{array}{r}\overline{40} 000 \\
33000 \\
100000 \\
95000\end{array}$ & $\begin{array}{r}\overline{95} \\
80 \\
0 \\
100\end{array}$ \\
\hline $526-550$ & $\begin{array}{l}1 \\
1 \\
1 \\
3 \\
1\end{array}$ & $\begin{array}{l}1 \\
1 \\
1 \\
1 \\
2\end{array}$ & $\begin{array}{l}100 \\
150(I P) \\
150 \\
200 \\
150-150\end{array}$ & $\begin{array}{l}100 \\
150 \\
150 \\
200 \\
300\end{array}$ & $\begin{array}{l}1 \\
1 \\
1 \\
3 \\
1\end{array}$ & $\begin{array}{l}0 \\
0 \\
0 \\
0 \\
0\end{array}$ & $\begin{array}{l}0 \\
1 \\
0 \\
3 \\
1\end{array}$ & $\begin{array}{l}1 \\
0 \\
1 \\
0 \\
0\end{array}$ & $\begin{array}{c}\overline{297} 450 \\
\overline{-} \\
1067500 \\
27000\end{array}$ & $\begin{array}{l}\overline{95-100} \\
\overline{-} \\
50-100 \\
100\end{array}$ \\
\hline $551-575$ & $\begin{array}{l}1 \\
5 \\
3\end{array}$ & $\begin{array}{l}1 \\
1 \\
1\end{array}$ & $\begin{array}{l}100 \\
150 \\
200\end{array}$ & $\begin{array}{l}100 \\
150 \\
200\end{array}$ & $\begin{array}{l}1 \\
5 \\
3\end{array}$ & $\begin{array}{l}0 \\
0 \\
0\end{array}$ & $\begin{array}{l}1 \\
4 \\
1\end{array}$ & $\begin{array}{l}0 \\
1 \\
2\end{array}$ & $\begin{array}{r}42250 \\
417900 \\
4000\end{array}$ & $\begin{array}{c}100 \\
0-100 \\
100\end{array}$ \\
\hline $576-600$ & $\begin{array}{l}2 \\
5\end{array}$ & $\begin{array}{l}1 \\
1\end{array}$ & $\begin{array}{l}100 \\
150\end{array}$ & $\begin{array}{l}100 \\
150\end{array}$ & $\begin{array}{l}2 \\
5\end{array}$ & $\begin{array}{l}0 \\
0\end{array}$ & $\begin{array}{l}2 \\
5\end{array}$ & $\begin{array}{l}0 \\
0\end{array}$ & $\begin{array}{r}995600 \\
2711440\end{array}$ & $\begin{array}{c}100 \\
90-100\end{array}$ \\
\hline $601-625$ & 2 & 1 & 150 & 150 & 2 & 0 & 2 & 0 & 1796880 & $30-100$ \\
\hline $\begin{array}{c}\text { Total } \\
200-626\end{array}$ & $\begin{array}{r}58 \\
6\end{array}$ & 2 & 0.9 p. 100 saline $\left({ }^{5}\right)$ & & $\begin{array}{r}54 \\
0\end{array}$ & $\begin{array}{l}4 \\
6\end{array}$ & $\begin{array}{r}38 \\
0\end{array}$ & $\begin{array}{r}20 \\
6\end{array}$ & & \\
\hline
\end{tabular}

(1) Only viable eggs were counted.

(2) Females were injected intramuscularly except where IP (intraperitonially) indicated.

(3) Figures indicate number of fish.

( ${ }^{4}$ First and second figures correspond to first and second injections, respectively.

(5) Control group, two 0.9 p. 100 saline injections given.

\section{Discussion.}

Induced spawning of Sparus aurata by means of HCG treatments was achieved previously (see references in the Introduction). Spawning was induced by several 
injections of HCG totaling 3500 to $5000 \mathrm{IU} / \mathrm{kg}$ fish, administered to females at the time of their natural spawning season. None of the previous studies with fish correlated the dose of the hormone used to oocyte developmental stage. In the present study, the HCG dose needed to induce oocyte development, ovulation and spawning at various stages of vitellogenesis was determined. Efficient HCG doses were found to be one to two orders of magnitude lower than doses used up to now. These doses were shown to relate inversely to the vitellogenetic stage of the oocytes.

The biopsy technique was found to have many potentialities : (1) It enabled us to determine the developmental stage of the oocytes, and hence to select only the appropriate females for treatment. (2) It allowed us to administer the selected hormone to the treated female in an effective way. Using this technique, the spawning season of Sparus aurata was extended to five and a half months. This result is a great advantage for mariculture since it permits a constant supply of larvae over a long period of the year.

The vast majority of the HCG treatments induced oocyte development and ovulation, whereas spawning response was induced in only part of the treated females. It is quite certain that each of the processes - maturation, ovulation and spawning of oocytes - involves different hormonal agents including gonadotropins, ovarian steroids and neurohypophysial hormones (Jalabert, 1976). The entire chain of events leading up to spawning of mature ovulated oocytes involves an elaborate complex of interactions. It is very probable that the gonadotropin treatments triggered this chain of events in most of the cases, but it was not completed in all of them, resulting in spawning responses.

Symposium sur lo Reproduction des Poissons Paimpont, France, 19-21 septembre 1977.

Résumé. Des expériences d'induction de la ponte de Dorades (Sparus aurafa) pratiquées au cours de 2 saisons de reproduction $1975-76$ et 1976-77 sont rapportées dans cet article. Les dorades élevées en captivité au laboratoire de mariculture d'Elat ne frayent pas spontanément. Au cours de la saison 1975-76 des injections intra-musculaires de HCG à des doses allant jusqu'à $2700 \mathrm{Ul} / \mathrm{kg}$ de poids vif corporel ont été pratiquées. Chaque traitement a été pratiqué en bassins séparés contenant quelques individus mâles et femelles. La plupart des femelles ont émis des ovules non matures ou surmatures. Cette méthode d'expérience n'a pas permis une analyse détaillée des traitements.

Au cours de la saison 1976-77, chaque femelle expérimentale a été placée en bassin séparé. Les doses d'HCG administrées ont été établies d'après l'état des ovocyłes (stade de vitellogenèse). Les doses suffisantes pour induire l'ovulation d'ovules viables et la fraie vont de 100 à $1200 \mathrm{UI} / \mathrm{kg}$ de poids vif. La saison de reproduction de la dorade en condition naturelle est supposée durer 6 semaines. Du fait des traitements avec HCG, la durée de la période de reproduction a été étendue à 5 mois et demi.

\section{References}

ALESSIO G., BRONZI P., 1974. Riproduzione artificiale di orata, Sparus aurata (L.) (Osteichthys, Sparidae). 1. Reperimento, transporto, stabulazione e trattmenti ormonali di riprodattori cresciuti nelle Valli Vente. Ateneo Paramense, Acta Nat., 10, 187-204.

ALESSIO G., GANDOLFI G., SCHREIBER B., 1975. Techniche e methodiche generali di riproduzione artificiale dell'orata, Sparus aurata (L.) (Osteichthys, Sparidae). Inv. Pesq., 39, 417-428. 
ALESSIO G., GANDOLFI G., SCHREIBER B., 1976. Induction de la ponte, élevage et alimentation des larves ef des alevins des poissons euryhalins. Etud. Rev., Cons. gén. Pêches Méditerr., FAO, 55, 143-157.

ARIAS A. M., 1976. Reproduction artificielle de la daurade Sparus aurata (L.). Efud. Rev., Cons. gén. Pêches Méditerr., FAO, 55, 159-173.

BARNABE G., 1976. Rapport technique sur la ponte induite et l'élevage des larves du loup Dicentrarchus labrax (L.) et de la daurade Sparus aurata (L.). Ełud. Rev., Cons. gén. Pêches Méditerr., FAO, 55, 63-116.

BARNABÉ G., RENÉ F., 1973. Reproduction contrôlée et production d'alevins chez la daurade Sparus aurata (Linné 1758). C. R. Acad. Sci. Paris, Sér. D, 276, 1621-1624.

DE VLAMING V. L., 1974. Environmental and endocrine control of teleost reproduction, 13-83. In SCHRECK C. B., Control of sex in fishes. Ext. Div., Virginia Polytech. Inst. State Univ., Blacksbury, Virginia.

JALABERT B., 1976. In vitro oocyte maturation and ovulation in rainbow trout (Salmo gairdneri), northern pike (Esox lucius) and goldfish (Carassius auratus). J. Fish. Res. Bd Can., 33, 974-983.

LUMARE F., VILLANI P., 1973. Artificial fertilization and larval rearing in Sparus aurata (L.) (Teleostea, Sparidae). Ichthyologia, 5, 87-97.

SAN FELIU J. M., MUNOZ F., AMAT F., RAMOS J., PEFFA J., SARZ A., 1976. Techniques de stimulation de la ponte et d'élevage de larves de crustacés et de poissons. Efud. Rev., Cons. gén. Pêches Médiferr., FAO, 55, 1-34.

SHEHADEH Z. H., 1970. Controlled breeding of culturable species of fish : a review of progress and current problems. Proc. Indo-Pacific Fish. Coun., FAO, 14th Sess., Thailand, 1-25.

VILLANI P., 1976. Ponte induite et élevage des larves de poissons marins dans les conditions de laboratoire. Ełud. Rev. Cons. gén. Pêches Méditerr., FAO, 55, 117-132.

ZOHAR Y., 1976. The gonadal cycle of the hermaphroditic feleost Sparus aurata. MSC. Thesis, Hebrew Univ. Jerusalem, Israel. 